\title{
Potioritas czy subbastacja? Pomiędzy dawnym prawem polskim a prawem francuskim $w$ egzekucji sądowej $w$ Księstwie Warszawskim i Królestwie Polskim*
}

\author{
Abstract \\ Potioritas or Subbastatio? Between Traditional Polish Law and French Law \\ in Enforcement Proceedings in the Duchy of Warsaw and the Kingdom of Poland
}

The French code of civil procedure of 1806 that was established in the Duchy of Warsaw in 1808 brought the institution of the sale of immovable property by auction (subhastatio) to the Polish legal system as a principal feature of enforcement proceedings. However, it was widely criticised as contradictory to the Polish traditional law that knew only exdivisione (potioritas). Exdivisione was based on granting the creditor possession of seized land, but without the loss of ownership by the debtor. French rules of enforcement proceedings in the Kingdom of Poland in 1823 were modified while the new institution that referred to exdivisione was introduced, that is, the bidding lease of the immovable property. Nevertheless, the new institution did not replace subhastatio entirely; exdivisione had been present in judiciary practice before, but with no legal ground.

Keywords: enforcement proceedings, civil procedure, potioritas, French code of civil procedure 1806, bailiff, Duchy of Warsaw, Kingdom of Poland, sale by auction of immovable property, subhastatio

Słowa kluczowe: postępowanie egzekucyjne, postępowanie cywilne, eksdywizja, potioritas, francuski kodeks postępowania cywilnego z 1806 r., komornik sądowy, Księstwo Warszawskie, Królestwo Polskie, licytacyjna sprzedaż nieruchomości, subhastacja

\footnotetext{
* Niniejsza publikacja została przygotowana w ramach projektu „Kodyfikacja narodowa - fantazmat czy realna alternatywa? W kręgu debat nad rodzimym systemem prawa sądowego w konstytucyjnym Królestwie Polskim" finansowanego ze środków Narodowego Centrum Nauki na podstawie umowy nr UMO-2015/18/E/ HS5/00762.
} 


\section{Wprowadzenie}

Początek XIX wieku w polskiej tradycji prawnej to czas wielkich przemian związanych $\mathrm{z}$ jednej strony $\mathrm{z}$ wprowadzeniem $\mathrm{w}$ Księstwie Warszawskim francuskich kodeksów cywilnego, handlowego i procedury cywilnej - a z drugiej strony z podjęciem działan, które nakierowane były na opracowanie własnych narodowych kodyfikacji już w okresie Królestwa Polskiego. Równolegle do prac nad Kodeksem Cywilnym Królestwa Polskiego komisja kodyfikacyjna przygotowywała projekt kodeksu procedury cywilnej, którego próba uchwalenia na sejmie w 1820 roku nie powiodła się ze względu na protesty rządu pruskiego ${ }^{1}$. Niemniej nie zaprzepaszczono całości prac, ponieważ część rozwiązań egzekucyjnych została przyjęta dwoma postanowieniami namiestnika Królestwa Polskiego z 8 lipca oraz 2 września 1823 roku$^{2}$. Wprowadziły one zakaz sprzedaży upraw na pniu, a także „zastąpiły” ${ }^{3}$ kodeksową subhastację ${ }^{4}$ przymusowym wydzierżawieniem nieruchomości w drodze licytacji. O ile obie kwestie można uznać za istotne z punktu widzenia praktyki, o tyle subhastacja była instytucją o szczególnym miejscu w debacie publicznej nad zmianami w egzekucji sądowej ${ }^{5}$. Uważano, że to francuskie rozwiązanie było co najmniej tak nieprzystające do polskich warunków społeczno-gospodarczych i tradycji prawnej jak francuskie prawo hipoteczne i powinno zostać jak najszybciej zmienione $^{6}$. Mimo to reforma nastąpiła dopiero w 1823 roku, czyli po niemal 15 latach stosowania najpierw w Księstwie Warszawskim, a później w Królestwie Polskim? W tym okresie typowym postulatem było przywrócenie potioritas, znanej dawnemu prawu polskiemu, i zastąpienia nią subhastacji, co miało być wyrazem „spolonizowa-

1 „W Procedurze zatem Cywilney obmyśonemi zostały srodki w doświadczeniu naddziadów czerpane, lecz proiekt w tey mierze z Kommissyami Seymowemi z stosownemi odmianami umówiony, lubo iako ogółowy dla wszystkich, szczególnym Konwencyom nie sprzeciwiaiący się z względów iednak w mądrości sprawiedliwego Monarchy ocenionych, został cofnionym” z wystąpienia sejmowego radcy stanu Kalinowskiego z 7 października 1820 r., w którym wcześniej wspominał o naciskach pełnomocnika rządu pruskiego (Dziennik posiedzeń izby poselskiej w czasie seymu Królestwa Polskiego w roku 1820, oprac. F. Obniski, Warszawa 1820, s. 177); H. Grynwasser, Niedoszty polski kodeks postepowania cywilnego (1820), „Kwartalnik Prawa Cywilnego i Karnego" 1918, nr 1, s. 127.

2 Postanowienie Namiestnika Królestwa Polskiego z 8 lipca 1823 r., Dziennik Praw Królestwa Polskiego [dalej: DPKP], t. 8, s. 93-99; Postanowienie Namiestnika Królestwa Polskiego z 2 września 1823 r., DPKP, t. 8, s. 148-195.

3 Czy było to zastąpienie, czy dodanie - o tym dalej.

4 Wedle M. Zatorskiego subhastacja była to sprzedaż licytacyjna nieruchomości, gdy sprzedaż licytacyjna ruchomości uważana była za aukcję (idem, O kontrakcie kupna zawartym w drodze licytacyi wedtug zasad prawa rzymskiego $i$ austriackiego z uwzględnieniem prawa pruskiego, francuskiego, saskiego $i$ projektu drezdeńskiego, wspólnego niemieckiego prawa o zobowiązaniach, Kraków 1868, s. 4).

5 A. Bielski, Sposoby do ocalenia maiatkow obywateli Xięstwa Warszawskiego od przypadków im zagrazaiacych stuzace przez A. Bielskiego Radom Departamentowym Xięstwa Warszawskiego za pozwoleniem zwierzchności do uwag podane, Kalisz 1809, s. 33; S. Wegrzecki, Uwagi nad powszechnem moratorium czyli odpowiedź na pismo Antoniego Bielskiego posła konińskiego, Warszawa 1810, s. 16; Dyaryusz Seymu Królestwa Polskiego 1818, wyd. N. Glücksberg, t. 2, Warszawa 1818, s. 1-12; K. Szaniawski, Uwagi o zabezpieczaniu i uskutecznianiu odpowiedzialności na dlużnikach dla wierzycieli, Warszawa 1820, s. 29-30;

6 H. Grynwasser, Niedoszty polski kodeks..., s. 83-86.

7 Tak ukształtowana procedura egzekucyjna obowiązywała aż do 1 stycznia 1876 r., kiedy to w Królestwie Polskim wprowadzona została rosyjska procedura cywilna z $1864 \mathrm{r}$. 
nia" francuskiej egzekucji ${ }^{8}$. Mimo że krytycy prawa francuskiego nad Wisłą słusznie podnosili staropolski charakter potioritas, to ich rozumienie tej instytucji zwykle nie miało zbyt wiele wspólnego z jej prawdziwą naturą - przede wszystkim nie była to instytucja postępowania egzekucyjnego. Subhastacja, czyli przymusowa sprzedaż licytacyjna nieruchomości w egzekucji sądowej, była na pozór instytucją nową, która zadłużonym posesjonatom zwiastowała utratę rodowych dóbr.

Zagadnienie praktyki związanej z potioritas, przymusowym wydzierżawieniem nieruchomości i subhastacją w Księstwie Warszawskim i Królestwie Polskim, wymagało zbadania, żeby ustalić relacje między tymi instytucjami zarówno w praktyce sądowej, na gruncie przepisów prawa, jak i w przekonaniu opinii publicznej. Badanie takie umożliwiły zachowane materiały praktyki, akty normatywne oraz wypowiedzi o charakterze naukowym i publicystycznym z epoki. Tematyka egzekucji sądowej w Księstwie Warszawskim i w Królestwie Polskim jest reprezentowana w piśmiennictwie naukowym w bardzo małym stopniu, choć należy wymienić artykuł Pauliny Kamińskiej pod tytułem $Z$ badań nad procedura licytacji w Królestwie Polskim do $1875 r .^{9}$ oraz Justyny Biedy zatytułowany Instytucja przymusu osobistego dtużników $w$ sprawach cywilnych na ziemiach Królestwa Polskiego w latach 1815-1875 ${ }^{10}$. Pozostałe publikacje mają charakter ogólny i przeglądowy ${ }^{11}$. Brak również pracy poświęconej analizie instytucji potioritas, subhastacji oraz reformie egzekucji sądowej z 1823 roku.

\section{Potioritas w dawnym prawie polskim}

Postępowanie egzekucyjne w polskim prawie ziemskim ${ }^{12}$ opierało się na egzekucji z nieruchomości, jak również na egzekucji osobistej w stosunku do nieposesjonatów ${ }^{13}$. Ta pierwsza nie prowadziła do sprzedaży licytacyjnej nieruchomości, a jej ewentualnym

8 Wypowiedź referendarza stanu Kajetana Koźmiana i debata nad potioritas (używano określenia: eksdywizja) w Radzie Stanu, zob. Archiwum Główne Akt Dawnych [dalej: AGAD], I Rada Stanu Królestwa Polskiego, sygn. 447, s. 319-320; S. Węgrzecki, Uwagi..., s. 16-17.

9 P. Kamińska, Z badań nad procedura licytacji w Królestwie Polskim do 1875 r., „Studia z Dziejów Państwa i Prawa Polskiego" 2016, nr 19, s. 211-220.

10 J. Bieda, Instytucja przymusu osobistego dtużników w sprawach cywilnych na ziemiach Królestwa Polskiego w latach 1815-1875, „Studia Iuridica Lublinensia” 2016, nr 25, s. 85-103.

11 D. Szpoper, I. Zdanowski, Egzekucja w procesie polskim - zarys historii instytucji, „Problemy Egzekucji” 1999, nr 1/37, s. 13-60. Artykuł ukazuje historię postępowania egzekucyjnego w Polsce w bardzo szerokiej perspektywie czasowej, odwołując się jedynie do tekstów normatywnych; M. Owsianka, Egzekucja sądowa w okresie Księstwa Warszawskiego i Królestwa Polskiego, „Przegląd Prawno-Ekonomiczny” 2012, nr 21, s. 50-58. Artykuł dotyczy co prawda postępowania egzekucyjnego w Księstwie Warszawskim i w Królestwie Polskim, ale autor ograniczył się jedynie do zacytowania treści i sporządzenia pobieżnej charakterystyki obowiązujących w epoce przepisów prawa w sposób nieuporządkowany, powierzchowny i niewystarczający.

$12 \mathrm{~W}$ prawie miejskim znana była również egzekucja z ruchomości, a w odniesieniu do nieruchomości również subhastacja (K. Bukowska, Proces w prawie miejskim [w:] Historia państwa i prawa Polski, t. 2: Od połowy XV wieku do r. 1795, red. J. Bardach, Z. Kaczmarczyk, B. Leśnodorski, Warszawa 1968, s. 424-425).

13 Z. Zdrójkowski, Proces ziemski [w:] Historia państwa i prawa Polski, t. 2: Od połowy XV wieku do r. 1795, red. J. Bardach, Z. Kaczmarczyk, B. Leśnodorski, Warszawa 1968, s. 403. 
punktem kulminacyjnym był zajazd na dobra, który mógł być przeprowadzony jedynie po wyczerpaniu długiej drogi sądowej i w porozumieniu z urzędem grodzkim. Głosów wzywających do powrotu tego modelu egzekucji sądowej (tzn. zajazdu) w XIX wieku w Księstwie Warszawskim i Królestwie Polskim nie było. Niemniej w debacie posługiwano się wspomnieniem o innej instytucji prawa staropolskiego, czyli eksdywizji. Należy zauważyć, że sama nazwa zdradza pewną nieścisłość, gdyż eksdywizja funkcjonowała w Wielkim Księstwie Litewskim, a ta sama instytucja w Koronie nazywana była potioritas - od reguly z konstytucji sejmowej z 1588 roku:

Deklarując in universum ważność zapisów, aby się ludzie nie zawodzili, pożyczaiąc pieniędzy super bona onerata: postanawiamy, iż kto będzie miał pierwszy prawo i zapis ad bona aliqua, tego będzie potioritas. I choćby też kto przezyski i possessyą za poślednieiszym zapisem otrzymał, tedy pierwszego zapisu summa i przezyski maią być ważniejsze i naprzod iść, wyiąwszy gdyby kto był triennalis possessor, albo de iure prawo iego nalazło się być nieważne ${ }^{14}$.

Obok tych dwóch określeń funkcjonowało jeszcze jedno, to znaczy rozbiór ${ }^{15}$. Postępowanie związane z potioritas nazywane było konkursem do majątku. Postępowania konkursowego nie traktowano jako części egzekucji, gdyż pojawiało się ono w kontekście prawa zobowiązań i przejawiało cechy, które pozwalałyby je dzisiaj zakwalifikować jako część prawa upadłościowego ze względu na swój charakter ${ }^{16}$.

Konkurs do majątku polegał na oddaniu wierzycielom majątku przez dłużnika, dla zaspokojenia ich pretensji, a także określeniu pierwszeństwa wśród wierzycieli. Rozróżniano konkurs dobrowolny - dłużnik sam poddawał majątek wierzycielom - albo przymusowy, gdy inicjowali go wierzyciele, a przyznawał sąd ${ }^{17}$. Do inicjacji konkursu dochodziło najczęściej z woli samego sukcesora (sukcesorów) dłużnika, gdy otrzymywał on zadłużony ponad miarę spadek. Sam konkurs był swego rodzaju inwentaryzacją obciążeń pochodzących z różnych tytułów. Rozpoczynał się od wyroku sądu, na podstawie którego na grunt zjeżdżali się sędziowie lub sędzia zjazdowy, a także strony. Następnie dokonywano likwidacji pasywów ciążących na majątku. Sąd zjazdowy miał prawo moderowania, czyli zmniejszania długów, dlatego dłużnik mógł utrzymać się przy dobrach, jeżeli podjął się spłaty zadłużenia ${ }^{18}$. Dokonywano następnie oszacowania majątku w ruchomościach i nieruchomościach, a gdy pasywa przewyższały aktywa, wtedy właściciel odprzysięgał się majątku, oddając go tym samym wierzycielom ${ }^{19}$. Kolejna czynność to tak zwane kolokowanie na majątku polikwidowanych uprzednio długów. Ważne, że dotyczyło to wszelkich długów - także niezapisanych na dobrach - choć wedle specjalnej kolejności: najpierw sumy uprzywilejowane, dalej sumy kapitałowe

14 Volumina Constitutionum, t. 2, vol. 2, wyd. S. Grodziski, Warszawa 2008, s. 70.

15 W. Dutkiewicz, Prawa Cywilne jakie w Polsce od roku 1347 do wprowadzenia Kodexu Napoleona obowiazywaty, Warszawa 1869, s. 216. „Stąd wykształciło się postępowanie w prawie Polski potioritas, w Litewskim exdywizją, teraz konkursem zwane. Zwano je także rozbiorem, czyli sprawą rozbiorową".

16 Ochrona interesu wierzyciela (tego z pierwszeństwem), niedopuszczenie do indywidualnego zaspokojenia wierzycieli w drodze egzekucji, ewentualne ocalenie części majątku dłużnika. Z. Zdrójkowski nazywał potioritas wprost upadłością, a także podkreślił jej procesowo-egzekucyjny charakter, zob. idem, Teodor Ostrowski (1750-1802) pisarz dawnego polskiego prawa sądowego, Warszawa 1956, s. 104.

17 Odpowiednio potioritas voluntaria oraz potioritas necessaria. Zob. T. Ostrowski, Prawo cywilne narodu polskiego, Warszawa 1787, s. 250-251; W. Dutkiewicz, Prawa Cywilne..., s. 216.

18 J. Rafacz, Dawne prawo sadowe polskie w zarysie, Warszawa 1936, s. 367.

19 Ibidem, s. 367. 
pożyczone dłużnikowi zapisane na dobrach (kolokowane wedle ich kolejności zapisania we właściwych aktach), później z kart ręcznych wedle czasu wystawienia, następnie bez daty, wtedy dopiero kollokowano sumy z długów słownych i weksli niezaprzysiężonych przez wierzycieli, a na końcu sumy z procentów od sum kapitałowych oraz sumy $\mathrm{z}$ kar nałożonych na dłużnika ${ }^{20}$. Po kollokowaniu sum dochodziło do ich tzw. aplikacji na majątek dłużnika. Przydzielano ocenione ruchomości (lub sumy należne dłużnikowi od osób trzecich). Obowiązywała zasada, że wierzycielowi umieszczonemu na dalszym miejscu przyznawano aplikację, o ile wcześniejszy przed nim wierzyciel w pełni zyskał zaspokojenie. Po tym dokonywano rzeczywistego podziału majątku nieruchomego między aplikowanych wierzycieli.

Wraz z wydzieleniem części następowało wwiązanie (przez woźnego), przez które wierzyciele obejmowali majątek w posiadanie, lecz nie dawało to im prawa własności, a jedynie prawo zastawu, które było rozumiane szczególnie i z zastawu wyróżniane. Przykładowo od 1791 roku zwykli zastawnicy byli dopuszczani do sejmików, o ile płacili określony podatek, a posiadacze z potioritas dopuszczani byli do nich bez ograniczeńn $^{21}$. Istotą tego posiadania była zasada, że mogli być oni wykupieni przez krewnych dłużnika, ale również przez wierzycieli, którzy „spadli” z tabeli.

Tak opisana potioritas doświadczyła w XVIII wieku licznych modyfikacji w konstytucjach sejmowych. W 1764 roku ustalono hierarchię między sędziami zjazdowymi, a ostatecznie w 1793 roku ustalono, że Trybunał mógł wysyłać na zjazdy sędziów ziemskich jedynie komorników ziemskich. Zmiany najdalej idące nastąpiły na sejmie grodzieńskim w 1793 roku, ponieważ wedle nowej organizacji sądów ziemskich zdaniem Józefa Rafacza „po kolokacji sum nie stosowano aplikacji na majątek, lecz sprzedawano majątek przez licytację prawem dziedzictwa wieczystego nigdy naruszyć się nie mogącym"22, a z ceny zyskanej w licytacji zaspokajano w całości wierzycieli wedle pierwszeństwa na podstawie kollokacji. Autor ten twierdził również, że taką zasadę stosowano już wcześniej w pojedynczych przypadkach pod wpływem praktyki miejskiej. Zgodnie z postanowieniami tego samego sejmu kluczową rolę w postępowaniu konkursowym odgrywać mieli komornicy ziemscy ${ }^{23}$, co ułatwia zrozumienie, dlaczego w Księstwie Warszawskim eksdywizja (potioritas) przypominała ówczesnym środek egzekucyjny par excellence, mimo że jej miejsce w prawie staropolskim, a także logika i zasady, było nieco inne. Trzeba jednak pamiętać, że prawo uchwalone na sejmie grodzieńskim nie weszło w życie ${ }^{24}$.

20 Ibidem, s. 368.

21 Ibidem.

22 Ibidem, s. 369; Volumina Legum, t. 10, oprac. Z. Kaczmarczyk, Poznań 1952, s. 94.

23 Ibidem, s. 252 i 289. Zarówno rola, jak i kompetencje komorników ziemskich były szerzej zakreślone niż późniejszych komorników sądowych, ale ważnym elementem wspólnym była egzekucja wyroków.

24 W. Dutkiewicz, Prawa cywilne..., s. 219-220. 


\section{Subhastacja w Księstwie Warszawskim i w Królestwie Polskim w latach 1808-1823}

Przepisy code de procédure civile z 1806 roku ${ }^{25}$ tworzyły model egzekucji sądowej oparty na sprzedaży licytacyjnej ruchomości i nieruchomości. Egzekucja z nieruchomości została uregulowana w tytułach XII i XIII księgi V części I francuskiego kodeksu²6, który obowiązywał w Księstwie Warszawskim razem z Kodeksem Napoleona od 1 maja 1808 roku, mimo że został wprowadzony w odmienny sposób - instrukcją ministra sprawiedliwości ${ }^{27}$ dopiero później potwierdzoną dekretem królewskim ${ }^{28}$. Niemal od samego początku przepisy o subhastacji budziły poważne wątpliwości opinii publiczneje ${ }^{29}$, a ich zmiana była ważnym tematem dyskusji sejmowej ${ }^{30}$.

Francuska procedura cywilna z 1806 roku była opisywana jako drobiazgowa i bardzo sformalizowana ${ }^{31}$. O ile opinia ta zdecydowanie pasowała do całości przepisów postępowania egzekucyjnego, o tyle w przypadku egzekucji z nieruchomości szczegółowość i formalizacja osiągnęły stopień najwyższy. Przejawem tego były liczne obowiązki urzędników i osób prywatnych w przedmiocie doręczania oryginałów

25 Korzystałem $\mathrm{z}$ oryginalnego wydania Code de procédure civile: édition originale et seule officielle (Paris 1806) oraz z thumaczeń Antoniego Łabęckiego Kodex postępowania sądowego cywilnego francuzkiego (Warszawa 1807) i Stanisława Zawadzkiego Prawo cywilne obowiqzujace w Królestwie Polskiem (t. 2, Warszawa 1861). Dalej jako KPC. Wszystkie cytaty za thumaczeniem ze zbioru S. Zawadzkiego.

26 Art. 673-748 KPC.

27 Instrukcya względem postępowania w sprawach cywilnych, wraz z reskryptem, przy którym takową Sądom przesłano [w:] Zbiór Przepisów Administracyjnych Królestwa Polskiego [dalej: ZPAKP], cz. II, t. 7, s. 7-47. Wydana 23 maja 1808 r.

28 Upoważnienie Ministra Sprawiedliwości do wydania Sądom Instrukcyi względem postępowania sądowego [w:] ZPAKP, s. 47-49. Wydane 4 lipca 1808 r.

29 H. Grynwaser, Kodeks Napoleona w Polsce [w:] idem, Kodeks Napoleona w Polsce. Demokracja szlachecka, 1795-1831, Wrocław 1951, s. 111.

30 Dyaryusz Seymu Królestwa Polskiego 1818, t. 2, s. 1-15.

31 „Wprowadzenie Kodexu Cywilnego do Exekucyi bez przygotowania, bez dokładnego wytłumaczenia i zastosowania do praw dawnieyszych, oraz zwyczaiów Narodowych (jak w innych Kraiach uczyniono) bez Sankcyi bez przepisania krótkiey, iasney, łatwey i niekosztowney Procedury, w nayznacznieyszej części przyczyniło się do cierpień Mieszkańca. Zawiłe i do zrozumienia trudne Sądownictwo daleka formalnościami przywalona, i do doyścia sprawiedliwości niepodobna droga, rozwlekła i Arbitralności ulegaiąca exekucya Dekretów" (Proźba postów i deputowanych Xięstwa Warszawskiego do Nayjasnieyszego Fryderyka Augusta króla saskiego xiążęcia warszawskiego: podana w czasie seymu w Warszawie dnia 14 grudnia 1811 r., Warszawa 1811, s. 6); ,Zawiłe i do zrozumienia trudne Sądownictwo, daleka, formalnościami przywalona, i do doyścia sprawiedliwości niepodobna droga, rozwlekła i Arbitralności ulegająca Exekucya Dekretów, niedokładne i do obłąkania prowadzące utrzymanie Xiąg Hipotecznych” (J. Godlewski, Glosy posła Maryampolskiego na Seymie roku 1811 w Warszawie miane z dotaczeniem uwag $i$ krótkiego namienienia niektórych w czasie Seymu czynności, Warszawa 1814, s. 8.); H. Grynwaser, Kodeks Napoleona w Polsce..., s. 65; według francuskiego komentatora $\mathrm{z}$ epoki miało to stanowić gwarancję bezpieczeństwa prawnego jednostki oraz zlikwidować wszelkie formy sędziowskiej arbitralności (J. Berriat-Saint-Prix, Cours de procédure civi$l e$, t. 1, Paris 1821, s. 6).

Artykuły - Articles 
i kopii nakazów zajęcia ${ }^{32}$, protokołów przeprowadzanych czynnościci33 oraz innych zaświadczeń ${ }^{34}$, a to wszystko w procedurze, która zakładała obowiązkowe kilkukrotne powtarzanie tej samej czynności ${ }^{35}$, co miało również wpływ na koszty. Postępowanie egzekucyjne z nieruchomości było wieloetapowe i podzielone przede wszystkim między trybunał cywilny oraz komornika sądowego (do 1 marca $1812 \mathrm{r}$. burgrabiego ${ }^{36}$ ) z mniejszym udziałem innych urzędników - konserwatora hipotek czy przedstawiciela lokalnej administracji. Wśród etapów należy wyróżnić: czynności związane z doręczeniem nakazu dłużnikowi, zajęcie nieruchomości rozpoczynające się wraz ze sporządzeniem protokołu zajęcia i zawiadomieniem dłużnika, a następnie zakładające publikacje obwieszczeń o zajęciu, dalej publikację objaśnień i warunków sprzedaży zajętej nieruchomości, na koniec sprzedaż licytacyjną, będącą dwuetapową, ponieważ składała się z licytacji przygotowawczej oraz ostatecznej ${ }^{37}$ - dzieliło je najczęściej około dwóch miesięcy ${ }^{38}$. Licytacje nieruchomości odbywały się na posiedzeniu trybunału cywilnego, któremu przewodniczył sędzia ${ }^{39}$, w warunkach przymusowego zastępstwa adwokackiego (patrona) ${ }^{40}$. Wyrazem formalizmu, który wpływał na skuteczność subhastacji

32 Zgodnie z art. $673 \mathrm{KPC}$ miało to mieć miejsce „osobiście lub w zamieszkaniu”, czyli albo do rąk własnych dłużnika, albo pozostawione na miejscu. Por. Archiwum Państwowe w Lublinie [dalej: APL], Konserwator Hipotek Departamentu Lubelskiego [dalej jako KHDL], sygn. 1, s. 13: „w zamieszkaniu dłużnika ur. Antoniego Skórzewskiego [tj. dłużnika], w którego niebytności tegoż ekonom Antoni Budnicki odebrał, na oryginale podpisał się".

${ }_{33}$ „Gazeta Warszawska” [dalej: GW] 1812, nr 45, s. 800-804. Egzekucja z licznych nieruchomości, tzn. z 2 miast (Bieżun i Żuromin) i 27 wsi (lub ich części) należących do dłużnika Adama Fortunata Kandyda Zaleskiego, na zaspokojenie wierzyciela Stanisława hr. Zamoyskiego wiązała się z doręczeniem kopii protokołu zajęcia nieruchomości do dwóch burmistrzów i licznych wójtów. Informacje o takich doręczeniach zawierało każde ogłoszenie właściwego trybunału cywilnego o przymusowej sprzedaży nieruchomości.

34 Na przykład art. 682 KPC traktujący o obowiązku doręczenia obwieszczeń o licytacjach nieruchomości burmistrzom i wójtom; Zob. APL, KHDL, sygn. 1, s. 42-64: na niepaginowanej karcie, znajdującej się na końcu przepisanego protokołu zajęcia dóbr Klesztowo, znalazły się zaświadczenia odbioru także za prefekta (i wielu innych), co świadczy o gorliwym wypełnianiu obowiązków przez urzędników w obawie przed błędami w egzekucji.

${ }^{35}$ Art. 702 KPC: „Zbiór objaśnień i warunków sprzedaży ogłoszony będzie na audiencji przynajmniej trzy razy przed przygotowawczym przysądzeniem, z przerwą dni piętnastu między ogłoszeniami”.

36 Dekret królewski z 14 października 1811 roku w sprawie woźnych sądowych i komorników, DPKPW t. 3, s. 407-413. Dekret wprowadził podział obowiązków burgrabiów między woźnych i komorników, ale kolejny dekret przedłużył termin wykonania tej zmiany do 1 marca 1812 r. Zob. Dekret z 28 października $1811 \mathrm{r}$. w sprawie przyspieszenia realizacji postanowień dekretu z 14 października $1811 \mathrm{r}$ o nominacji komorników i woźnych [w:] Ustawodawstwo Księstwa Warszawskiego. Akty normatywne władzy najwyższej, oprac. W. Bartel, J. Kosim, W. Rostocki, Warszawa 1964, t. 1, s. 156.

37 Mogła wystąpić jednak trzecia licytacja tych samych dóbr w warunkach określonych w art. 710 KPC, czyli tzw. nadlicytacja. Por. Wyrok Sądu Kasacyjnego z 20 lutego 1816 r. za Recueil général des lois et des arrêts : en matière civile, criminelle, commerciale et de droit public, red. J.-B. Sirey, Paris 1818, s. 437.

38 Musiało upłynąć co najmniej sześć tygodni wedle art. 706 KPC. Zdarzało się, że trybunały wyznaczały obie licytacje z przerwą minimalną. Przy subhastacji wsi Bramki Górne w powiecie błońskim licytacja przygotowawcza odbyła się 4 lipca 1811 r., a ostateczna została wyznaczona na 15 sierpnia 1811 r. (GW 1812, nr 85, s. 1614). Przerwa zwykle wynosiła dwa lub nawet trzy miesiące (GW 1812, nr 75, s. 1439: przerwa od 16 lipca do 10 października 1812 r. przy subhastacji wsi Potok).

${ }_{39}$ GW 1812, nr 64, s. 1199-1200; W Trybunale Cywilnym Kaliskim w posiedzeniu licytacyjnym wzięło udział 3 sędziów ( $w$ tym prezes wydziału), prokurator królewski, asesor, woźny oraz pisarz (AGAD, Trybunał Cywilny Kaliski [dalej: TCK], sygn. 7, k. 7).

40 Takie rozwiązanie miało zabezpieczyć pewność licytacji, ponieważ adwokaci byli zawodowymi pełnomocnikami procesowymi przedstawiającymi wysoki standard moralny. We wcześniejszym stanie praw- 
i możliwość jej unieważnienia, były liczne środki zaskarżenia - przede wszystkim zwykła opozycja, ale również opisane w specjalnym tytule XII księgi V części I francuskiego kodeksu, poświęconym sporom incydentalnym przy egzekucji z nieruchomości ${ }^{41}$, jak zbieg egzekucji (art. 719-725), apelacja przeciwko wyrokowi, na podstawie którego dokonano zajęcia (art. 726-730), zarzuty nieważności przeciw postępowaniu poprzedzającemu przysądzenie przygotowawcze (art. 733-736) i relicytacja (art. 737-745). Stąd też dłużnicy, czyli właściciele licytowanych dóbr, dysponowali licznymi środkami obrony przed egzekucją, które były wnoszone na każdym etapie postępowania ${ }^{42}$.

Ważnym zagadnieniem praktyki egzekucyjnej na gruncie kodeksu z 1806 roku była możliwość przejęcia przez wierzyciela nieruchomości dłużnika w wyniku subhastacji. Było to dopuszczalne, a w świetle zachowanego materiału archiwalnego - wręcz nagminne. Zespół Trybunału Cywilnego Kaliskiego zawiera liczne protokoły, wedle których przysądzenie licytacyjne następowało na rzecz wierzycieli. Umożliwiał to art. 698 KPC, w którym uregulowano, że w przypadku braku licytantów przysądzenie następowało na rzecz popierającego ,za położoną przez niego cenę" ${ }^{\text {"w3 }}$. Niezależnie od tego, czy francuski ustawodawca miał na myśli popierającego egzekucję czy popierającego licytację (innego nabywcę), to protokoły z posiedzeń licytacyjnych z lat 1810-1811 potwierdzają, że to wierzyciele zwykle brali udział w licytacjach. Dla przykładu w trakcie sprzedaży dóbr Wszotowa i Jankowa należących do dłużnika Pawła Rychtowskiego, a popieranej przez sukcesorów po małżeństwie Bogdańskich, w trakcie drugiej licytacji, na której dojść miało do przysądzenia ostatecznego, zaraz po przeczytaniu warunków sprzedaży patron strony popierającej oświadczył, że „Sami zaś sukcesorowie za pomienione dobra summę $200000 \mathrm{zl}$ polskich ofiarowali”"44. W innej sprawie $\mathrm{z}$ tego okresu wierzyciel Ignacy Prądzyński przejął dobra Łaszów, należące do jego dłużnika

nym we Francji w okresie obowiązywania regulacji z roku VII, gdy nie było obowiązkowego zastępstwa adwokackiego, w trakcie przymusowej sprzedaży licytacyjnej nieruchomości, dłużnicy w celu jak najdłuższego utrzymania własności nieruchomości konsekwentnie doprowadzali do upadku licytacji poprzez licytowania przez osoby trzecie, które w momencie przysądzenia okazywały się niewypłacalne. Wierzyciele stawali przed alternatywą egzekucji z majątku nabywcy lub dokonania kolejnej sprzedaży nieruchomości w drodze licytacji, ale na koszt nabywcy (P.J.H. Thomine-Desmazures, Commentaire sur le code de procédure civile, t. 3 , Bruksela 1839, s. 108).

${ }^{41}$ Instytucje i czynności określone jako incydentalne przy popieraniu egzekucji z nieruchomości tym różniły się od uprawnienia, że zawsze zależały od oceny i uznania sądu, czyli w myśl zdania ce n'est pas de droit, c'est un incident à juger, zob. P.J.H. Thomine-Desmazures, Commentaire..., t. 3, s. 122. Komentarz do art. $722 \mathrm{kpc} w$ odniesieniu do różnicy między prawem do subrogacji przy zajęciu ruchomości i jedynie możliwością wnioskowania o subrogację przed sądem w przypadku zajęcia nieruchomości.

${ }^{42}$ Już po licytacji dóbr Jankowo, ale przed przysądzeniem, przed Trybunałem Cywilnym w Kaliszu okazało się, że dłużnik wniósł wcześniej apelację, która miała skutek zawieszający (AGAD, TCK, sygn. 6, k. 551-557/s. 489-495); Przed Trybunałem Cywilnym w Warszawie doszło do licytacji dóbr Czaplinek i Czarnylas pomimo apelacji i opozycji (GW 1812, nr 42, s. 754.); licytacja dóbr Wszotowa, których właściciel (dłużnik) Paweł Rychtowski starał się unieważnić licytację i przysądzenie ze względu na popełnione drobne błędy proceduralne przez burgrabiego w czasie dokonania zajęcia. Kaliski trybunał podtrzymał zajęcie w mocy (AGAD, TCK, sygn. 5, k. 6 i 295).

43 Mogło się to odnosić do popierającego egzekucję albo do popierającego licytację. We francuskim oryginale użyto słowa le poursuivant, które tłumaczone było tradycyjnie na język polski jako ,popierający egzekucję". To samo określenie znalazło się w thumaczeniach Antoniego Łabęckiego - licząc od pierwszego wydania. W późniejszym tłumaczeniu zamieszczonym w zbiorze Stanisława Zawadzkiego z lat 60. XIX w. znalazło się określenie „nabywca” zamiast „popierający”.

${ }_{44}$ AGAD, TCK, sygn. 6, k. 174 (s. 162). 
Jana z Dukli Molskiego, po dwóch zaciętych licytacjach. W trakcie pierwszej licytacji przygotowawczej cena urosła z wywoławczej kwoty 70000 zł do 106000 zł wskutek rywalizacji między patronem Franciszkiem Jarzembowskim (pełnomocnikiem wierzyciela $^{45}$ ) a Feliksem Więckowskim ${ }^{46}$. Należy również podnieść ważną okoliczność, że z analizy treści zbiorów objaśnień i warunków sprzedaży za te lata (1810-1811) wynika, iż suma szacunkowa wartości nieruchomości podawana przez wierzycieli często odpowiadała kwocie zadłużenia ${ }^{47}$. Wierzyciel był zainteresowany przejęciem nieruchomości jak najmniejszym kosztem, co prowadziło do zaniżenia przez niego jej ceny szacunkowej. Proceder ten zakończyło postanowienie króla saskiego z 26 czerwca 1811 roku ${ }^{48}$, w którym określono, że dobra nieruchome wystawione przymusowo na sprzedaż publiczną nie mogły być przysądzane niżej dwóch trzecich ich wartości. We wstępie tego postanowienia podano najważniejsze problemy dotychczasowej subhastacji, czyli powszechny brak gotówki ${ }^{49}$, co doprowadzało do pokrzywdzenia dłużników, uszczerbku wiary publicznej i kredytu, a także samych wierzycieli (innych niż popierającego egzekucję), a same dobra sprzedawane miały być za bezcen. Postanowienie to przywróciło zasadę znaną z okresu pruskiego ${ }^{50}$, której brak we francuskim kodeksie procedury cywilnej uznawany był za szczególną niedogodnośćs1. Należy zauważyć, że także w dawnym prawie polskim można znaleźć zakaz sprzedaży dóbr poniżej ich ceny szacunkowej ${ }^{52}$. Postanowienie z 26 czerwca 1811 roku obowiązywało w Królestwie Polskim tak długo jak francuska procedura cywilna z roku 1806, czyli w praktyce do 1 stycznia 1876 roku. Postulaty jego liberalizacji wysuwali Jan Kanty Wołowski oraz Hipolit Chwalibóg i dotyczyły one przede wszystkim samej procedury szacunkowej, która sprawiała stronom

45 Okazało się to po złożeniu deklaracji przez patrona po wygraniu licytacji w kancelarii trybunału (AGAD, TCK, sygn. 6, k. 477).

46 Ibidem, k. 239 i n.

47 Wierzytelność w kwocie 150000 zł znalazła odzwierciedlenie w warunkach sprzedaży folwarków Kociołki i Gacie, gdyż nabywca licytacyjny tych folwarków był zobowiązany do uiszczenia takiej samej kwoty w trzech ratach po $5000 \mathrm{zł}$ (AGAD, TCK, sygn. 1153, k. 8-9).

48 Dziennik Praw Księstwa Warszawskiego (dalej DPKW), t. 3, s. 351-353.

49 Z wysokimi cenami nieruchomości próbowano radzić sobie przez rozkładanie płatności na raty, choć problemy z płatnością ostatnich rat potwierdzają warunki sprzedaży, w których pojawiały się zastrzeżenia, że brak płatności którejkolwiek z rat w terminie doprowadzał do przepadku rat już opłaconych i ponownej licytacji. Dodatkowym zabezpieczeniem był warunek, że nabywca wejdzie w posiadanie nie wcześniej niż po zapłaceniu całości sumy licytacyjnej (zob. AGAD, TCK, sygn. 1153, k. 75-76), czy poddanie się nabywcy pod egzekucję (zob. AGAD, TCK, sygn. 1154, k. 23/2). W zabezpieczeniu samej licytacji wśród warunków udziału w niej mógł znaleźć się obowiązek uprzedniego wpłacenia vadium (zob. AGAD, TCK, sygn. 1153, k. 70).

50 W tytule 52 § 48 części I Powszechnej Ordynacji Sądowej dla Państw Pruskich zastrzeżono, że ,Jeżeli na subhastowane dobra szlacheckie ofiarowano mniej niż dwie trzecie części taxy, przybicie nie ma miejsca, jeżeli się na nie nie zgadzają wszyscy interesanci” (I. Stawiarski, Ogulna Ordynacya Sądowa dla Państw Pruskich, Warszawa 1809, t. 2, s. 505-506).

51 J.K. Wołowski, Czy w subhastacyach taxa pod prekluzya i kosztem dłużika może bydź nakazywana, „Themis Polska. Pismo Nauce i Praktyce Prawa Poświęcone” 1830, t. 7, s. 441-448; W. Nowakowski, Czy prawo z dnia 26 Czerwca 1811 roku o szacowaniu dóbr nieruchomych, w drodze wywłaszczenia przymuszonego sprzedawanych, stosuje się do nieruchomości miejskich?, „Przegląd Sądowy. Pismo Popularno-Naukowe Poświęcone Teoryi i Praktyce Prawa” 1868, t. 1, s. 182-186.

52 W 1793 r. na sejmie grodzieńskim w „Ustanowieniu Komisji do rozsądzenia sprawy upadłych krajowych banków” uregulowano, że „nigdy jednak niżej nad taksę przedane być nie mają, której to sprzedaży sposób i urządzenia komisji oddajemy” (Volumina Legum, t. 10, s. 94). 
duże trudności, a także w znacznym stopniu obciążała wymiar sprawiedliwości, co miało negatywne skutki dla systemu kredytowego w Królestwie Polskim ${ }^{53}$.

\section{Przymusowe wydzierżawienie nieruchomości w drodze licytacji w Księstwie Warszawskim i Królestwie Polskim}

Zarzut formalizmu wobec francuskiego postępowania egzekucyjnego traktowany był zwykle jako wstęp do krytyki subhastacji ${ }^{4}$, która była kojarzona raczej z niebezpieczeństwem utraty przez dłużnika rodowych dóbr, a nie z gwarancją dla wierzycieli, czyli kredytodawców. Postanowienie Księcia Namiestnika z 8 lipca 1823 roku ${ }^{55}$, znoszące zajmowanie produktów rolnych na pniu, było zapowiedzią aktu prawnego ingerującego w o wiele większym stopniu we francuskie rozwiązania egzekucyjne przyjęte razem z francuskim kodeksem procedury cywilnej w dobie Księstwa Warszawskiego. Kolejne postanowienie Księcia Namiestnika, z 2 września 1823 roku $^{56}$, oficjalnie przygotowane jako uzupełnienie art. 4 postanowienia lipcowego, było dłuższe (zawierało 59 artykułów) oraz zmieniało postępowanie egzekucyjne w Królestwie Polskim w sposób zasadniczy, ponieważ wprowadziło nieznaną prawu francuskiemu instytucję egzekucji z nieruchomości w drodze jej wydzierżawienia przez licytację. Postanowienie miało mieć charakter prowizoryczny i obowiązywać, „nim [nowy] Kodex postępowania sądowego stale zaprowadzonym będzie" 57 - czyli aż do 1 stycznia 1876 roku.

Przymusowe wydzierżawienie nieruchomości odbywało się nie na posiedzeniu trybunału cywilnego (jak w przypadku subhastacji), ale przed notariuszem ${ }^{58}$. W związku z tym to na komorniku sądowym, a nie na trybunale cywilnym, spoczywał ważny obowiązek publikacyjny i informacyjny ${ }^{59}$. To również komornik w porozumieniu z wierzycielem przygotowywał warunki licytacji ${ }^{60}$. Doprecyzowane zostały przepisy o publikacji ogłoszeń w art. 17, ponieważ wymagane było dwukrotne ogłoszenie na 30 i 15 dni przed terminem licytacji w dzienniku właściwego województwa i w „Gazecie Warszawskiej”. O ile licytacje dzierżawy nieruchomości miejskich mogły odbywać się w każdym terminie w ciągu roku, o tyle nowością było ograniczenie terminu w przypadku nieruchomości wiejskich, gdyż wydzierżawienie mogło nastąpić jedynie od 24 czerwca, czyli od tradycyjnego terminu dzierżawy na św. Jana, dlatego wymagano przeprowadzenia licytacji w maju lub w czerwcu (art. 15). W związku z powyższym w „Gazecie Warszawskiej” sporadycznie odnajdujemy ogłoszenia o licytacjach dzierżawy nieruchomości miejskich,

53 W. Witkowski, Aleksander This i Jan Kanty Wołowski. Wybitni prawnicy Królestwa Polskiego, Lublin 2001, s. 190-191.

54 Uwagi Rolnika do Seymuiacych, b.m.w., 1820, s. 16.

55 DPKP, t. 8, s. 93-99.

56 DPKP, t. 8, s. 148-195.

57 Ibidem, s. 148.

58 Art. 3 postanowienia, zob. DPKP, t. 8, s. 153.

59 Liczne ogłoszenia komorników, zob. GW 1826, nr 33, s. 466: m.in. ogłoszenie komornika przy Trybunale Cywilnym w Kaliszu, Marcina Drzewieckiego, o licytacji dzierżawy kamienicy w Kaliszu.

60 Art. 16 postanowienia, zob. DPKP, t. 8, s. 165. 
ale im bliżej 24 czerwca, dodatki do gazety zalewane były ogłoszeniami komorniczy$\mathrm{mi}^{61}$. Jeśli zachodziła potrzeba przeprowadzenia drugiej licytacji tych samych dóbr, wtedy musiało to nastąpić najpóźniej w lipcu. Gdy z jakichś powodów dodatkowy termin nie zakończył się sukcesem (brak chętnych, nieuczciwy licytant etc.), wtedy notariusz, po konsultacjach z wierzycielami przeprowadzonymi najpóźniej w październiku, ustanawiał tymczasową administrację zajętych dóbr, a kolejna licytacja była przenoszona na kolejny rok zgodnie z art. 15 (art. 26). Termin kontraktu dzierżawnego wynosił najwyżej trzy lata, chyba że wszyscy wierzyciele zgodzili się na jego wydłużenie (art. 16).

W najnowszych opracowaniach z zakresu historii prawa wejście w życie postanowienia z 2 września 1823 roku oznaczało dwie rzeczy. Po pierwsze, zamienienie sprzedaży licytacyjnej nieruchomości na egzekucję przez wydzierżawienie nieruchomości. Po drugie, przywrócenie polskiego modelu postępowania egzekucyjnego i tym samym zniesienie modelu francuskiego ${ }^{62}$. Obie tezy w takiej formie są sprzeczne zarówno z praktyką egzekucyjną, która nastąpiła po 1823 roku, jak również z brzmieniem przepisów.

Egzekucja przez przymusową licytację dzierżawy zajętej nieruchomości porównywana była do staropolskiej potioritas. Nie jest to precyzyjne, ponieważ potioritas nie zawierała elementu licytacji i mogła mieć charakter dobrowolny ${ }^{63}$. Z tego powodu potioritas nie traktowano jako części egzekucji sądowej. Licytacja dzierżawy nieruchomości nie wiązała się również z kollokacją i aplikacją, jako że była ona zgodna z prawem hipotecznym Królestwa Polskiego. Autorzy reformy nie zadali sobie trudu zbadania niuansów dawnej potioritas, i to mimo faktu, że odpowiadająca jej eksdywizja była wówczas ciągle w użyciu na Litwie ${ }^{64}$. Licytacja dzierżawy była raczej podobna do pruskiego sekwestru nieruchomości ${ }^{65}$ z Powszechnej Ordynacji Sądowej dla państw pruskich z 1793 roku, obowiązującej przecież na ziemiach, z których w 1807 roku powstało Księstwo Warszawskie. Nieprawdziwa jest również teza, że licytacja dzierżawy nawiązująca do potioritas została przywrócona po latach nieobecności. Przekonanie takie mogło wynikać z ograniczeń dawnych badań do ustawodawstwa i źródeł normatywnych, w których

${ }^{61}$ W dodatku do numeru z 9 czerwca znalazło się aż 13 ogłoszeń komorników o licytacjach dzierżawy różnych dóbr wiejskich (GW 1826, nr 91).

62 K. Sójka-Zielińska, Królestwo Polskie 1816-1863. Postępowanie cywilne [w:] Historia Państwa i Prawa Polski, t. 3: Od rozbiorów do uwłaszczenia, Warszawa 1981, s. 521-522; M. Owsianka, Egzekucja sądowa..., s. 53.

63 J. Rafacz, Dawne prawo..., s. 366.

64 Na łamach „Dziennika Wileńskiego” w 1816 r. opublikowano aż trzy artykuły poświęcone eksdywizji (wszystkie bardzo krytyczne), zob. O haniebnym zbywaniu majątków, czyli po naszemu exdywizyach. Wywód historyczno-prawoznawczy. Rzecz wzięta z dzieła Pittmanna Profesora prawa w Uniwersytecie lipskim, „Dziennik Wileński” 1816, t. 3, nr 14, s. 140-158; J. Chodźko, O exdywizyach czyli o podziale majątku dtużnika dla wierzycielów. Rosprawa Jana Chodzki Prezydenta, „Dziennik Wileński” 1816, t. 4, nr 21, s. 194-227; W. Gadon, O exdywizyach z powodu rosprawy Pana Prezydenta Chodzki. Uwagi Włodzimierza Gadona, „Dziennik Wileński” 1816, t. 4, nr 24, s. 506-518; jedynym członkiem polskiej Rady Stanu, który ogólnie alarmował o trudnościach związanych z eksdywizją na Litwie, był Ludwik Plater: „Exdywizyi odraczał tenże radca jej przyjęcie jako w żadnej części Europy nieznanej oprócz w Litwie i na Wołyniu, gdzie najsmutniejszy zrządziwszy stan mieszkańców kredyt zupełnie zniszczyła i kapitały martwymi zrobiła. Jeżeliby zaś środek ten satysfakcji wierzycieli przyjętym został na taki przypadek wnosił Radca, ażeby los włościan był zabezpieczony i ażeby ci z miejsca nie mogli być ruszani” (AGAD, I Rada Stanu Królestwa Polskiego, sygn. 447, s. 319).

65 Sekwestr nieruchomości miejskich i wiejskich został opisany w § 116-140 w tytule 24 . części I ordynacji, por. I. Stawiarski, Ogulna Ordynacya ..., t. 1, s. 597-606. 
- aż do omawianego postanowienia z 2 września 1823 roku - nie było żadnych przepisów umożliwiających licytację dzierżawy nieruchomości. Źródła praktyki przemawiają za odrzuceniem tej tezy. W spuściźnie Trybunału Cywilnego w Warszawie można odnaleźć liczne dowody ${ }^{66}$ na to, że omawiana instytucja była w sposób całkowicie pozakodeksowy ${ }^{67}$ stosowana przez cały okres istnienia Księstwa Warszawskiego i później, a w 1823 roku doszło jedynie do jej sformalizowania. Dlaczego tak szybko pojawiła się instytucja wydzierżawienia obok kodeksowej sprzedaży licytacyjnej? Z prawnego punktu widzenia sprzedaż licytacyjna zajętej nieruchomości była skutecznym i definitywnym środkiem doprowadzającym postępowanie egzekucyjne do szczęśliwego, dla wierzyciela, końca. Z perspektywy praktyki i obrotu gospodarczego dostrzegamy inny obraz tej instytucji. Sprzedawane nieruchomości, w przeważającej liczbie dobra ziemskie kilkanaście lub nawet kilkadziesiąt razy droższe od nieruchomości miejskich, były zbyt drogie jak na możliwości nabywców stawających do licytacji ${ }^{68}$. Niewiele zmienił dekret króla saskiego z 26 czerwca 1811 roku, zakazujący sprzedaży zajętych nieruchomości poniżej dwóch trzecich ich wartości, co było wymierzone w sprzedaż nieruchomości znacznie poniżej ich wartości, ale w żaden sposób nie wpłynęło na możliwości finansowe nabywców, a ponadto wprowadzało kolejną czynność formalną do i tak bardzo sformalizowanej procedury egzekucyjnej i zwiększało koszty postępowania, które w tym wypadku pozostawały po stronie dłużnika ${ }^{69}$. W związku z tym suma przybicia już w warunkach sprzedaży, przygotowywanych przez stronę popierającą egzekucję, dzielona była na kilka rat, a coraz bardziej zaostrzająca się odpowiedzialność nabywcy za niewykonanie tego świadczenia ${ }^{70}$ sygnalizuje, że powszechnie wierzyciele napotykali trudności z wyegzekwowaniem kolejnych rat (oprócz pierwszej, zwykle opłacanej $\mathrm{w}$ terminie zastrzeżonym w warunkach licytacyjnych). Przyjmując powyższe założenia, wprowadzenie pozakodeksowego środka egzekucji w postaci ustanowienia na zajętej nieruchomości dzierżawy i wydzierżawienia jej w drodze licytacji, która potocznie nazywana była „licytacją dzierżawy/wydzierżawienia dóbr" "71, było sposobem na rozwiązanie tego problemu, gdyż dzierżawa rozpisywana była tylko na kilka lat, suma była o wiele niższa niż w przypadku sprzedaży, a w związku z tym szanse na znalezienie odpowiedniego nabywcy-dzierżawcy rosły. Wieloletnie stosowanie tej instytucji - co warto odnotować: bez żadnej podstawy prawnej - w latach 1808-1823 potwierdziła sama

${ }^{66}$ Jako że tylko niewielka część zespołu archiwalnego Trybunału Cywilnego w Warszawie zachowała się do naszych czasów, w zastępstwie przywoływane są tu ogłoszenia tego trybunału zlecane przez jego pisarza, a także tamtejszych burgrabiów i komorników, zamieszczane w „Gazecie Warszawskiej” (GW 1812, nr 10, s. 175; ibidem, nr 31, s. 550; ibidem, nr 34, s. 605; ibidem, nr 35, s. 624; ibidem, nr 36, s. 646; ibidem, nr 49, s. 870).

67 To znaczy przepisy o przymusowej sprzedaży licytacyjnej stosowane były odpowiednio.

68 Szacunek ceny dóbr ziemskich, czyli detaksacja, nie opierał się na próbie określenia wartości rynkowej. Kwestia ta była przedmiotem wymiany zdań, zainicjowanej przez Ludwika Platera, na posiedzeniu zgromadzenia ogólnego Rady Stanu z 21 lipca 1820 r. (AGAD, I Rada Stanu Królestwa Polskiego, sygn. 447, s. 318-319).

${ }^{69}$ W. Witkowski, Aleksander This..., s. 120-121.

70 Por. warunki sprzedaży w początkowym okresie oraz po kilku latach stosowania francuskich przepisów (AGAD, TCK, sygn. 1153 i 1154).

71 GW 1812, nr 35, s. 624; ibidem, nr 45, s. 805. 
Rada Stanu w swoim raporcie z działalności rządu i stanu kraju w latach 1820-1823 przedstawionym na posiedzeniu sejmu 14 maja 1825 roku $^{72}$.

\section{Podsumowanie}

Wejście w życie postanowienia z 2 września 1823 roku nie oznaczało likwidacji subhastacji. W praktyce sądowej od 1823 roku można znaleźć niemal wyłącznie zajęcia nieruchomości celem wydzierżawienia, czyli w myśl nowego postanowienia. Jednakowoż sporadycznie w materiale źródłowym reprezentowane są zajęcia, ogłoszenia i sprzedaż licytacyjna nieruchomości w „starym” trybie ${ }^{73}$. Prowadzi to do tezy, zgodnie z którą w egzekucji z nieruchomości wydzierżawienie nie zastąpiło sprzedaży, ale stanowiło nową dodatkową instytucję ${ }^{74}$. Była ona preferowana przez wierzycieli, komorników, a także dłużników, którzy nie byli pozbawiani własności, ale tylko posiadania, i w konsekwencji zdominowała praktykę egzekucyjną. Ponadto trzeba podkreślić, że art. 1 postanowienia z 2 września 1823 roku został sformułowany w następujący sposób: „Każdemu wierzycielowi wolno jest na mocy wyroku i aktu do execucyi upoważniającego, zaymować na satysfakcyą w drodze exekucyi sądowey nieruchomości wieyskie celem ich wydzierżawienia"75. Nie wspomniano o uchyleniu przepisów o sprzedaży licytacyjnej nieruchomości, a wierzyciel „mógł”, lecz nie musiał, wybrać nowo wprowadzony środek egzekucyjny. Jeżeli chodzi o tezę o całkowitym odejściu od modelu francuskiego i wprowadzenie rozwiązań staropolskich, to również nie można się z nią zgodzić. Reforma doprowadziła do rozszerzenia katalogu środków egzekucyjnych, a nie do ich zastąpienia. Poza tym dyskusja w Radzie Stanu dowiodła, że głównym naturalnym punktem odniesienia twórców reformy były przepisy francuskiego kodeksu, których logika również przeniknęła do treści postanowienia z 2 września 1823 roku $^{76}$. Oznacza to, że nie przywrócono wprost instytucji dawnego prawa polskiego, ale jedynie

${ }^{72}$ „Środek ten [wydzierżawienie dóbr dłużnika na satysfakcję wierzycieli - TK] tyle okazał się stosownym do stanu kraju, iż nie będąc przepisanym procedurą cywilną, przecież przez zwyczaj prawie we wszystkich trybunałach przyjęty, już poprzednio był używany" (Obraz Królestwa Polskiego w okresie konstytucyjnym, Raporty Rady Stanu Królestwa Polskiego z działalności rząu w latach 1816-1828, oprac. J. Leskiewiczowa, F. Ramotowska, Warszawa 1984, s. 205).

73 Dla przykładu ogłoszenie pisarza Trybunału Cywilnego Województwa Mazowieckiego w Warszawie o sprzedaży licytacyjnej dóbr ziemskich Lubieniec. Zajęcie zostało dokonane w $1825 \mathrm{r}$. i wpisane do księgi wieczystej nieruchomości (GW 1826, nr 91, s. 1423). W tym samym numerze ukazało się inne ogłoszenie o sprzedaży licytacyjnej dóbr Knurowa zamieszczone przez pisarza Trybunału Cywilnego Województwa Podlaskiego (GW 1826, nr 91, s. 1427).

${ }_{74}$ Odmiennie twierdził S. Płaza: „W szczególności zamiast dotychczasowej licytacyjnej sprzedaży nieruchomości wiejskich i miejskich przewidywano ich zajęcie i licytacyjne wydzierżawienia, a wierzyciele zaspakajani byli z dochodów dzierżawnych" (idem, Historia Prawa w Polsce na tle porównawczym, cz. II: Polska pod zaborami, Kraków 2002, s. 148).

75 DPKP, t. 8, s. 149.

76 Rada pracowała nad projektem postanowienia na trzech posiedzeniach: kolejno 22, 25 i 29 sierpnia 1823 r. Wprost zwracano się o przywróceniem niektórych rozwiązań francuskich - np. dłuższych terminów na ogłoszenia przedlicytacyjne - co Rada ostatecznie uwzględniła. (AGAD, I Rada Stanu Królestwa Polskiego, sygn. 461, s. 444). 
zmodyfikowano rozwiązania francuskie na podstawie wyobrażenia o tym, jak funkcjonowała w okresie staropolskim potioritas. Było to zatem połączenie idei, która cieszyła się sławą „narodowej” z wykorzystaniem aparatu i wzorów pochodzących z nowego prawa francuskiego.

\section{Bibliografia}

Źródła archiwalne

Archiwum Główne Akt Dawnych:

I Rada Stanu Królestwa Polskiego, sygn. 447 i 461;

Trybunał Cywilny Kaliski, sygn. 5, 6, 7, 1153 i 1154.

Archiwum Państwowe w Lublinie:

Konserwator Hipotek Departamentu Lubelskiego, sygn. 1.

Źródła wydane

Bielski A., Sposoby do ocalenia maiątkow obywateli Xięstwa Warszawskiego od przypadków im zagrazaiących stuzace przez A. Bielskiego Radom Departamentowym Xięstwa Warszawskiego za pozwoleniem zwierzchności do uwag podane, Kalisz 1809.

Code de procédure civile: édition originale et seule officielle, Paris 1806.

Dyaryusz Seymu Królestwa Polskiego 1818, wyd. N. Glücksberg, t. 2, Warszawa 1818.

Dziennik posiedzeń izby poselskiej w czasie seymu Królestwa Polskiego w roku 1820, oprac. F. Obniski, Warszawa 1820.

Dziennik Praw Królestwa Polskiego, t. 8.

Dziennik Praw Księstwa Warszawskiego, t. 3.

„Gazeta Warszawska” 1812 (nr 10, 31, 34, 35, 36, 42, 45, 49, 64, 75, 85), 1826 (nr 33 i 91).

Godlewski J., Głosy posła Maryampolskiego na Seymie roku 1811 w Warszawie miane z dołaczeniem uwag i krótkiego namienienia niektórych w czasie Seymu czynności, Warszawa 1814.

Kodex postępowania sądowego cywilnego francuzkiego, tłum. A. Łabęcki, Warszawa 1808.

Obraz Królestwa Polskiego w okresie konstytucyjnym, Raporty Rady Stanu Królestwa Polskiego z działalności rządu w latach 1816-1828, oprac. J. Leskiewiczowa, F. Ramotowska, Warszawa 1984.

Proźba postów i deputowanych Xięstwa Warszawskiego do Nayjasnieyszego Fryderyka Augusta króla saskiego xiążęcia warszawskiego: podana w czasie seymu w Warszawie dnia 14 grudnia $1811 \mathrm{r}$., Warszawa 1811.

Recueil général des lois et des arrêts : en matière civile, criminelle, commerciale et de droit public, red. J.-B. Sirey, Paris 1818.

Stawiarski I., Ogulna Ordynacya Sądowa dla Państw Pruskich, Warszawa 1809, t. 2.

Szaniawski K., Uwagi o zabezpieczaniu i uskutecznianiu odpowiedzialności na dtużnikach dla wierzycieli, Warszawa 1820.

Ustawodawstwo Księstwa Warszawskiego. Akty normatywne władzy najwyższej, oprac. W. Bartel, J. Kosim, W. Rostocki, Warszawa 1964, t. 1.

Uwagi Rolnika do Seymuiacych, b.m.w. 1820.

Volumina Constitutionum, t. 2, vol. 2, wyd. S. Grodziski, Warszawa 2008. 
Volumina Legum, t. 10, oprac. Z. Kaczmarczyk, Poznań 1952.

Węgrzecki S., Uwagi nad powszechnem moratorium czyli odpowiedź na pismo Antoniego Bielskiego posta konińskiego, Warszawa 1810.

Zawadzkiego S., Prawo cywilne obowiązujące w Królestwie Polskiem , t. 2, Warszawa 1861.

Zbiór Przepisów Administracyjnych Królestwa Polskiego. Wydziat Sprawiedliwości, cz. II, t. 7, Warszawa 1867.

\section{Opracowania}

Berriat-Saint-Prix J., Cours de procédure civile, t. 1, Paris 1821.

Bieda J., Instytucja przymusu osobistego dlużników w sprawach cywilnych na ziemiach Królestwa Polskiego w latach 1815-1875, „Studia Iuridica Lublinensia” 2016, nr 25.

Bukowska K., Proces w prawie miejskim [w:] Historia państwa i prawa Polski, t. 2: Od połowy $X V$ wieku do r. 1795, red. J. Bardach, Z. Kaczmarczyk, B. Leśnodorski, Warszawa 1968.

Chodźko J., O exdywizyach czyli o podziale majątku dłużnika dla wierzycielów. Rosprawa Jana Chodzki Prezydenta, „Dziennik Wileński” 1816, t. 4, nr 21.

Dutkiewicz W., Prawa Cywilne jakie w Polsce od roku 1347 do wprowadzenia Kodexu Napoleona obowiązywaty, Warszawa 1869.

Gadon W., O exdywizyach z powodu rosprawy Pana Prezydenta Chodzki. Uwagi Włodzimierza Gadona, „Dziennik Wileński” 1816, t. 4, nr 24.

Grynwaser H., Kodeks Napoleona w Polsce [w:] H. Grynwaser, Kodeks Napoleona w Polsce. Demokracja szlachecka, 1795-1831, Wrocław 1951.

Grynwasser H., Niedoszły polski kodeks postępowania cywilnego (1820), „Kwartalnik Prawa Cywilnego i Karnego" nr 1, Warszawa 1918.

Kamińska P., Z badań nad procedura licytacji w Królestwie Polskim do 1875 r., „Studia z Dziejów Państwa i Prawa Polskiego" 2016, nr 19.

Nowakowski W., Czy prawo z dnia 26 Czerwca 1811 roku o szacowaniu dóbr nieruchomych, $w$ drodze wywtaszczenia przymuszonego sprzedawanych, stosuje się do nieruchomości miejskich?, „Przegląd Sądowy. Pismo Popularno-Naukowe Poświęcone Teoryi i Praktyce Prawa” 1868 , t. 1.

O haniebnym zbywaniu majątków, czyli po naszemu exdywizyach. Wywód historyczno-prawoznawczy. Rzecz wzięta z dzieła Pittmanna Profesora prawa w Uniwersytecie lipskim, „Dziennik Wileński” 1816, t. 3, nr 14.

Ostrowski T., Prawo cywilne narodu polskiego, Warszawa 1787.

Owsianka M, Egzekucja sądowa w okresie Księstwa Warszawskiego i Królestwa Polskiego, „Przegląd Prawno-Ekonomiczny” 2012, nr 21.

Płaza S., Historia Prawa w Polsce na tle porównawczym, cz. II: Polska pod zaborami, Kraków 2002.

Rafacz J., Dawne prawo sądowe polskie w zarysie, Warszawa 1936.

Sójka-Zielińska K., Królestwo Polskie 1816-1863. Postepowanie cywilne [w:] Historia Państwa i Prawa Polski, t. 3: Od rozbiorów do uwłaszczenia, Warszawa 1981.

Szpoper D., Zdanowski I., Egzekucja w procesie polskim - zarys historii instytucji, „Problemy Egzekucji” 1999, nr 1/37.

Thomine-Desmazures P.J.H., Commentaire sur le code de procédure civile, t. 3, Bruksela 1839.

Witkowski W., Aleksander This i Jan Kanty Wołowski. Wybitni prawnicy Królestwa Polskiego, Lublin 2001.

Wołowski J.K., Czy w subhastacyach taxa pod prekluzya i kosztem dlużnika może bydź nakazywa$n a$, ,Themis Polska. Pismo Nauce i Praktyce Prawa Poświęcone” 1830, t. 7.

Zatorski M., O kontrakcie kupna zawartym $w$ drodze licytacyi wedtug zasad prawa rzymskiego 
i austriackiego z uwzględnieniem prawa pruskiego, francuskiego, saskiego i projektu drezdeńskiego, wspólnego niemieckiego prawa o zobowiąaniach, Kraków 1868.

Zdrójkowski Z., Proces ziemski [w:] Historia państwa i prawa Polski, t. 2: Od połowy XV wieku do r. 1795, red. J. Bardach, Z. Kaczmarczyk, B. Leśnodorski, Warszawa 1968.

Zdrójkowski Z., Teodor Ostrowski (1750-1802) pisarz dawnego polskiego prawa sądowego, Warszawa 1956. 